\title{
Cultivation strategies of a BA/F3 cell line for fundamental cell research
}

\author{
Martin Schaletzky ${ }^{1}$, Oscar Platas Barradas ${ }^{1}$, Henning Sievert ${ }^{2}$, Stefan Balabanov², An-Ping Zeng ${ }^{1}$, Ralf Pörtner ${ }^{1 *}$ \\ From 22nd European Society for Animal Cell Technology (ESACT) Meeting on Cell Based Technologies \\ Vienna, Austria. 15-18 May 2011
}

\section{Background}

During the chronic myelogenous leukemia (CML) the Bcr-Abl oncoprotein is produced, which leads to unregulated cell proliferation. CML is treated with one of several targeting therapies such as imatinib, (formerly STI-571 [Glivec; Novartis, Switzerland]) a selective inhibitor that blocks tyrosin kinase activity of the Bcr-Abl oncoprotein. Apart from the second generation Bcr-Abl inhibitors, identifying novel direct or indirect downstream targets of Bcr-Abl could contribute significantly to the development of new synergistic treatment strategies against CML. The effects of imatinib on the protein expression of Bcr-Abl positive cells are being investigated [1]. A protein which is downregulated during treatment with imatinib (eukaryotic translation initiation factor eIF5A) was identified. This protein is a potentially promising target for single-agent and combined-treatment strategies for CML. For protein complex identification a high cell number is needed. This is difficult to be obtained reproducibly with flask cultures or roller bottles. The aim of this project was to develop and establish a reproducible bioreactor cultivation of murine suspension cell lines (BA/F3 p210), which yields a total cell number close to $1 \cdot 10^{10}$ cells required for analytics. Cells should be in exponential growth under constant culture conditions at the time of harvest. A small stirred tank bioreactor with a working volume of $150 \mathrm{~mL}$ was used to study and compare different operation modes: batch, fed-batch and continuous. Cell growth and glucose consumption were assessed as main culture parameters.

\footnotetext{
* Correspondence: poertner@tuhh.de

${ }^{1}$ Institute of Bioprocess and Biosystems Engineering, Hamburg University of Technology, Hamburg, D-21073, Germany

Full list of author information is available at the end of the article
}

\section{Material and methods}

Cell lines: BA/F3 p210 and BA/F3 p210 eIF5A-2 (BA/ $\mathrm{F} 3=$ mouse pro $\mathrm{B}$ cells, $\mathrm{p} 210=\mathrm{Bcr}-\mathrm{Abl}$ oncoprotein $(210 \mathrm{kDa})$, eIF5A-2 $=$ isoform of the eukaryotic translation initiation factor eIF5A).

In a first step, a working cell bank was established and cell growth was characterized in T-flasks. Afterwards, different cultivation modes were tested in a stirred tank bioreactor (Vario1000, Medorex, Germany) as follows:

batch: Cultivation volume $\mathrm{V}_{\text {start }}=350 \mathrm{~mL}$, duration: $40 \mathrm{~h}$

fed-batch: Cultivation volume $\mathrm{V}_{\text {start }}=345 \mathrm{~mL}$, duration: $64 \mathrm{~h}$, Feeding took place every time Glucose concentration fell below $2 \mathrm{mM}$. Feed medium consisted on a mixture of batch medium and higher concentrations of glucose and glutamine.

Continuous: Cultivation volume $\mathrm{V}_{\text {start }}=115 \mathrm{~mL}$, dilution rate $\mathrm{D}=0.049 \mathrm{~h}^{-1}$ duration: $118.5 \mathrm{~h}$.

The scale-up experiment was performed in a $5 \mathrm{~L}$ stirred bench-top bioreactor (Biostat B, Sartorius Stedim Biotech $\mathrm{GmbH}$ ) with $\mathrm{pH}$ and DO control.

\section{Results and conclusions}

In batch mode, the maximum viable cell density during exponential growth was $\mathrm{VCD}_{\max }=14.7 \cdot 10^{5}$ cells $\mathrm{mL}^{-1}$. In fed-batch mode $\mathrm{VCD}_{\max }=22.6 \cdot 10^{5}$ cells $\mathrm{mL}^{-1}$. This higher cell density is an advantage over the batch culture mode. It was not possible to obtain higher cell densities in this mode, since the feed medium consisted on a formulation for batch culture with further addition of glucose and glutamine. In continuous mode the highest possible cell density was maintained in the bioreactor, in order to produce continuously cells for further treatment. A maximum cell yield of $8.3 \cdot 10^{6}$ cells $^{-1}$ could be harvested from the bioreactor. After scale-up, this yield might be increased, so that the needed cell number could be harvested in only few days. A disadvantage of 


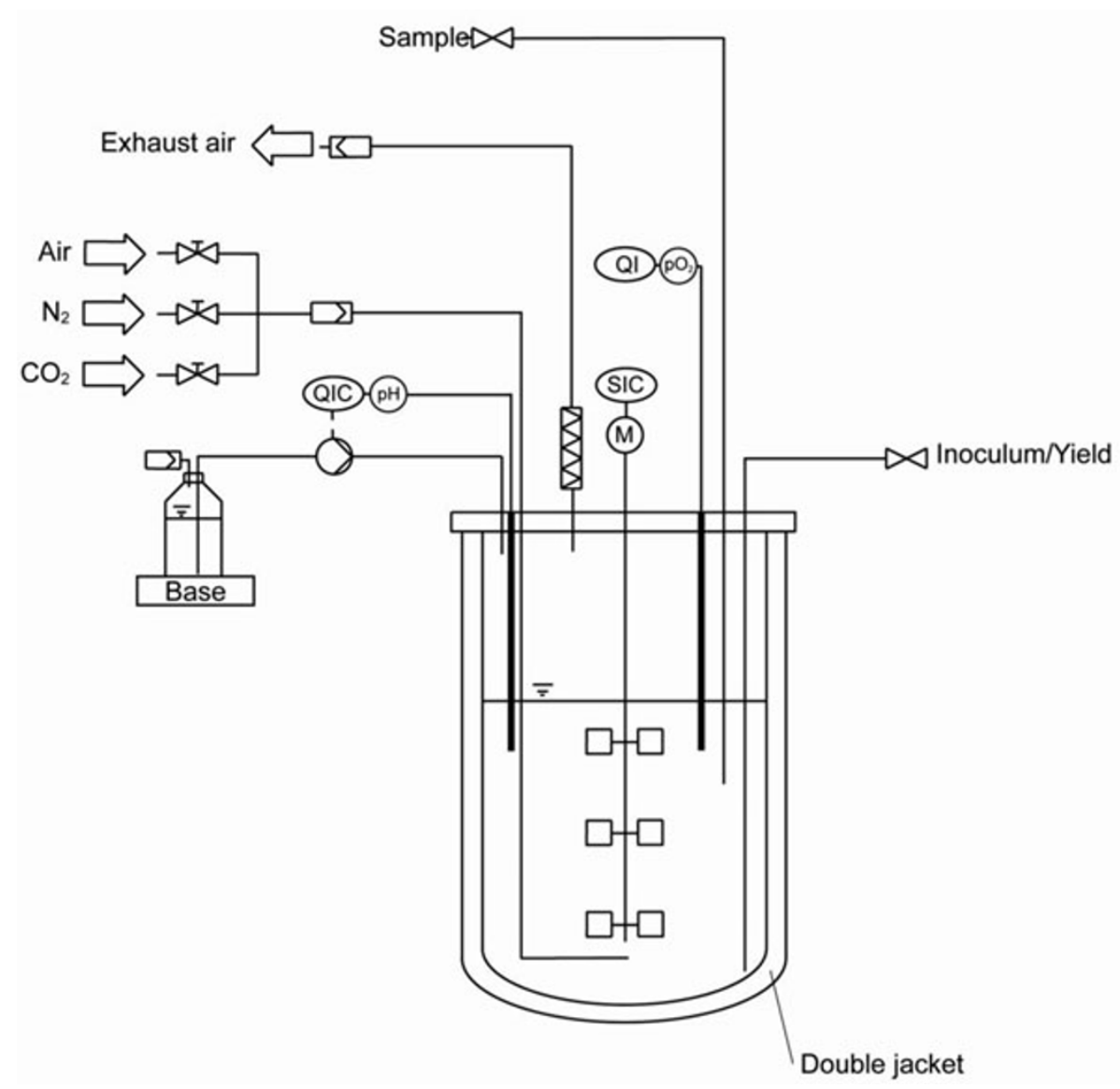

Figure 1 Schematic diagram of the final batch process in a $5 \mathrm{~L}$ bioreactor that yields a total cell number close to $1 \cdot 10^{10}$

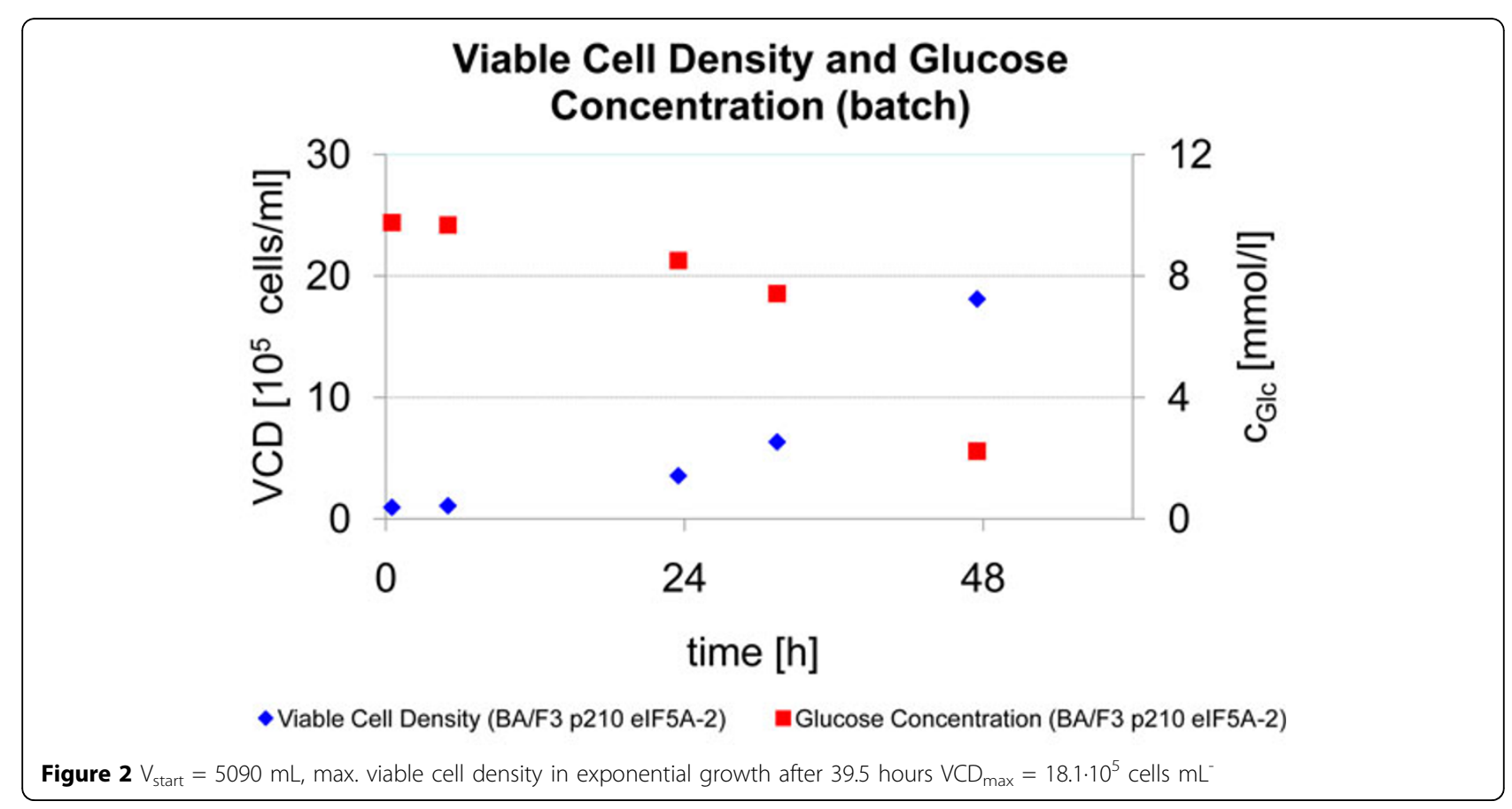


the continuous process with cell harvest was observed for the storage process, since cell lysis took place after storage at $4{ }^{\circ} \mathrm{C}$.

A first approach for scale-up was performed in the $5 \mathrm{~L}$ bioreactor (Figure 1), where the maximum cell density during exponential phase allowed for the needed cell number. Regarding the required reproducibility for cultivation, the $5 \mathrm{~L}$ batch mode was preferred over T-flasks due to the possibility for control of process variables like $\mathrm{pH}$ and $\mathrm{pO}_{2}$.

Compared to T-flasks, glucose uptake during bioreactor cultivation was much higher, which led to lower final-cell-density yields. fed-batch and continuous modes were firstly favored due the theoretical final cell numbers reached during culture. However, the difference in growth, limitation of bioreactor volume and the need of a special medium formulation for higher cell densities during fed-batch, limited the final yield. Continuous mode with temperature reduction of harvested cells allowed for constant cell production in exponential phase. On the other hand, storage of intact cells was limited probably due to protease action. The $150 \mathrm{~mL}$ batch cultivation was scaled up to $5 \mathrm{~L}$ in a stirred bench-top bioreactor (Biostat B, Sartorius Stedim Biotech $\mathrm{GmbH}$ ).

\section{Author details}

${ }^{1}$ Institute of Bioprocess and Biosystems Engineering, Hamburg University of Technology, Hamburg, D-21073, Germany. ${ }^{2}$ Cancer Center Hamburg, University Medical Center Hamburg-Eppendorf (UKE), Hamburg, D-20246, Germany.

Published: 22 November 2011

\section{Reference}

1. Balabanov $S$, et al: Hypusination of eukaryotic initiation factor $5 A$ (elF5A): a novel therapeutic target in BCR-ABL-positive leukemias identified by $a$ proteomics approach. Blood 2007, 109(4).

doi:10.1186/1753-6561-5-S8-P48

Cite this article as: Schaletzky et al:: Cultivation strategies of a BA/F3 cell line for fundamental cell research. BMC Proceedings 2011 5(Suppl 8):P48.

\section{Submit your next manuscript to BioMed Central} and take full advantage of:

- Convenient online submission

- Thorough peer review

- No space constraints or color figure charges

- Immediate publication on acceptance

- Inclusion in PubMed, CAS, Scopus and Google Scholar

- Research which is freely available for redistribution

Submit your manuscript at www.biomedcentral.com/submit 